\title{
FACTORS AFFECTING TRICHLORETHYLENE VAPOUR CONCENTRATIONS
}
A. W. ConN, M.D.,
A. E. DYER, M.A., **
and $J$.
K. W. FERGUSON, M.D. ${ }^{*}$

Thrs investigation was carried out to determine the trichlorethylene concentrations delivered by a standard anaesthetic apparatus, and to assess the alteration of these concentrations with changes in $(a)$ valve opening, $(b)$ rate of gaseous flow, $(c)$ fluid volume, and $(d)$ liquid temperature.

\section{METHOD}

A standard Airmed anaesthetic machine with a Marrett head was used. The valve openings on the head of the trichlorethylene bottle were graded as $1,2,3$ and 4 (marked FULL). The trichlorethylene vapour, carried by nitrous oxide, passed through a 36-inch piece of rubber tubing to attain room temperature. A half-litre glass weighing bottle, with valves at its inlet and outlet, could be attached. By experiment, it was found that at a flow rate of five litres or greater, for a period of one minute, complete displacement, for practical purposes, occurred.

The valve opening, volume of trichlorethylene, and the gaseous How rate were pre-arranged for each experiment. The gas was allowed to flow continuously for 90 minutes. At each fifteen-minute interval, a sample was taken, and the trichlorethylene temperature and volume with the room temperature and atmospheric pressure were recorded.

The sample was collected by connecting the weighing bottle and tubing for one minute. The bottle was then weighed, flushed with nitrous oxide for one minute, and re-weizhed. From the change in weight, the trichlorethylene vapour concentration coulc be calculated using the following formula:

$$
\underset{(\text { vols } \%)}{\text { Trichlorethylene }}=\frac{224}{G} \times \frac{760 t}{273 p} \times \frac{100}{v} \times \Delta W,
$$

where $G=$ the difference in weight at N T.P. of the gram molecular weights of nitrous oxide and trichlorethylene.

$t=$ ambient temperature in degrees absolute

$p=$ atmospheric pressure in mm. Mercury.

$v=$ volume of weighing bottle in litres.

$W=$ change in weight of bottle in grams.

\section{Results}

The first group of experiments was carned out to determine the effect of altering the gaseous rate of flow. With the initial volume constant $(90 \mathrm{cc}$ ), the

"From the Department of Pharmacology, University of Toronto, and the Hospital for Sick Children, Toronto, Canada

* From the Department of Pharmacology, Unversity of Toronto.

$\nmid$ Kindly loaned by the Imperial Surgical Co Ltd, 80 Sherboune St., Toronto. 
trichlorethylene vapour concentration was determined for each valve opening using flows of $5,6,7,8,9$, and 10 litres per minute.

Using valve opening 4, the vapour concentrations during each experiment varied greatly. The results are presented in Fig. 1 and they also illustrate the high initial concentrations with a rapid fall observed only with valve opening, 4. In this group of experiments the gas invariably "bubbled" through the trichiorethylene producing a high degree of vaporization. Isolated examples within these experiments revealed that marked decreases in vapour concentration occurred, despite a constant low temperature.

Using valve openings 1,2 , and 3, "bubbling" was not observed and the vapour concentration, within each experiment, varied only slightly after equilibration. Therefore an average concentration for each whole experiment was taken and is reported in Table I.

\section{TABLE I}

Trichlorethylene Vapotr Concentration's

\begin{tabular}{cccc}
\multicolumn{4}{c}{$($ vol $\%)$} \\
\hline L/M & \multicolumn{3}{c}{ Valve opening } \\
\hline 5 & 1 & 2 & 3 \\
\hline 6 & $<1$ & 1 & 8 \\
7 & 1 & 4 & 12 \\
8 & 1 & 7 & 8 \\
9 & 1 & 5 & 6 \\
10 & 1 & 6 & 6 \\
\hline
\end{tabular}

A similar group of experiments was carried out to determine the effect of altering the volume of liquid trichlorethylene. With a constant flow rate of 8 litres per minute, the vapour concentrations were determined for each valve opening, using $30,60,90$, and $120 \mathrm{cc}$. of trichlorethylene. These results are reported in Fig 2 and Table II.

TABLE II

Trichlorethylene Vapour Concentratio's (vol \%)

\begin{tabular}{|c|c|c|c|}
\hline \multirow{2}{*}{$\begin{array}{l}\text { Volume of } \\
\text { liquid }\end{array}$} & \multicolumn{3}{|c|}{ V'alve opening } \\
\hline & 1 & 2 & 3 \\
\hline $30 \mathrm{cc}$ & $<1$ & $9^{*}$ & $12^{*}$ \\
\hline $60 \mathrm{cc}$ & $<1$ & 2 & 3 \\
\hline $90 \mathrm{cc}$ & 1 & 5 & 6 \\
\hline $120 \mathrm{cc}$ & $<1$ & 2 & $8^{*}$ \\
\hline
\end{tabular}

*Indicates surface disturbance

A survey of the preceding experiments was made to observe any effect on vapour concentrations. due to chang, in temperature of the trichlorethylene. In half the experiments, there was no cetectable change in the trichlorethylene con- 
centrations, although a mean fall of $4.2 \pm 0.6^{\circ} \mid \mathrm{C}$. below room temperature occurred. Where there was a greater fall in temperature, due to bubbling, the average fall below room temperature was 15.4 ( \pm S.D. 0.4$)^{\circ}$ C. In these experiments it was not possible to separate the reduction in concentration due to cooling from that due to other factors.

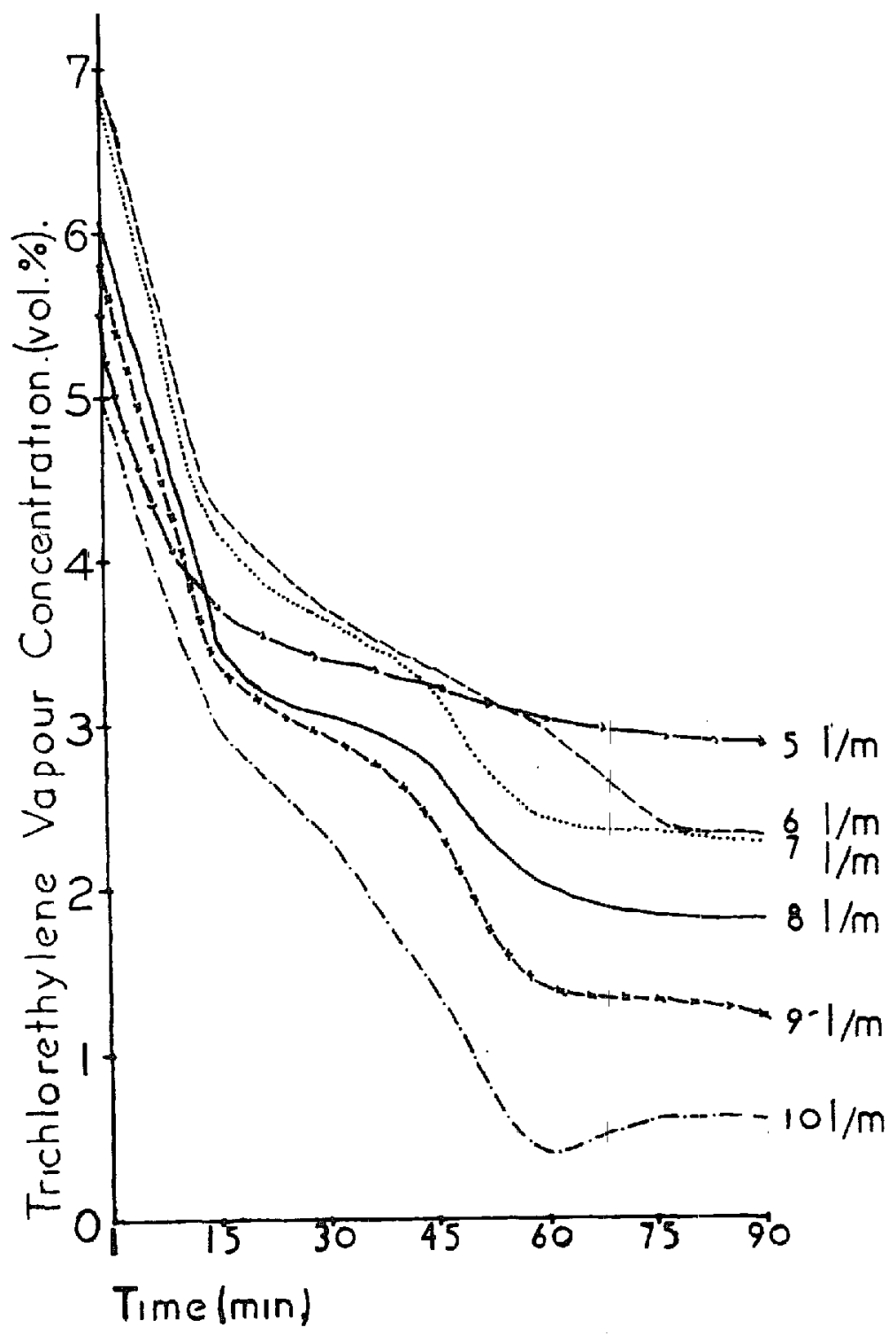

Fic. 1. Valve opening 4; liquid vol. $90 \mathrm{cc}$.

\section{Discussion}

In Fig. 1 is shown the reduction in concentration that occurs with increasing flow rate. When valve opening 4 is used, the rate of vaporization is maximal so that by increasing the flow rate, dilution occurs and the trichlorethylene concen $\uparrow$ tration decreases.

The data shown in Table I were examined by a standard analysis of variance. The difference in vapour concentrations at valve openings 1,2 , and 3 was significant as shown by the $f$ test with $\mathrm{p}<0.001$. Similarly it was shown that, in 
general, the difference in vapbur concentrations at different flows between $\mathbf{5}$ and 10 litres per minute was not significant $(p>0.05)$. However, there would seem to be a tendency with increasing flow rate for the vapour concentrations to reach a maximum and then diminish.

The information in Fig. 2 suggests that a relationship exists between trichlorethylene vapour concentration and liquid volume, when valve opening 4 is used. As the level of liquid is raised, the gas must "bubble" through a greater distance and, consequently, vaporization is increased. When a $30 \mathrm{cc}$. volume is used, a

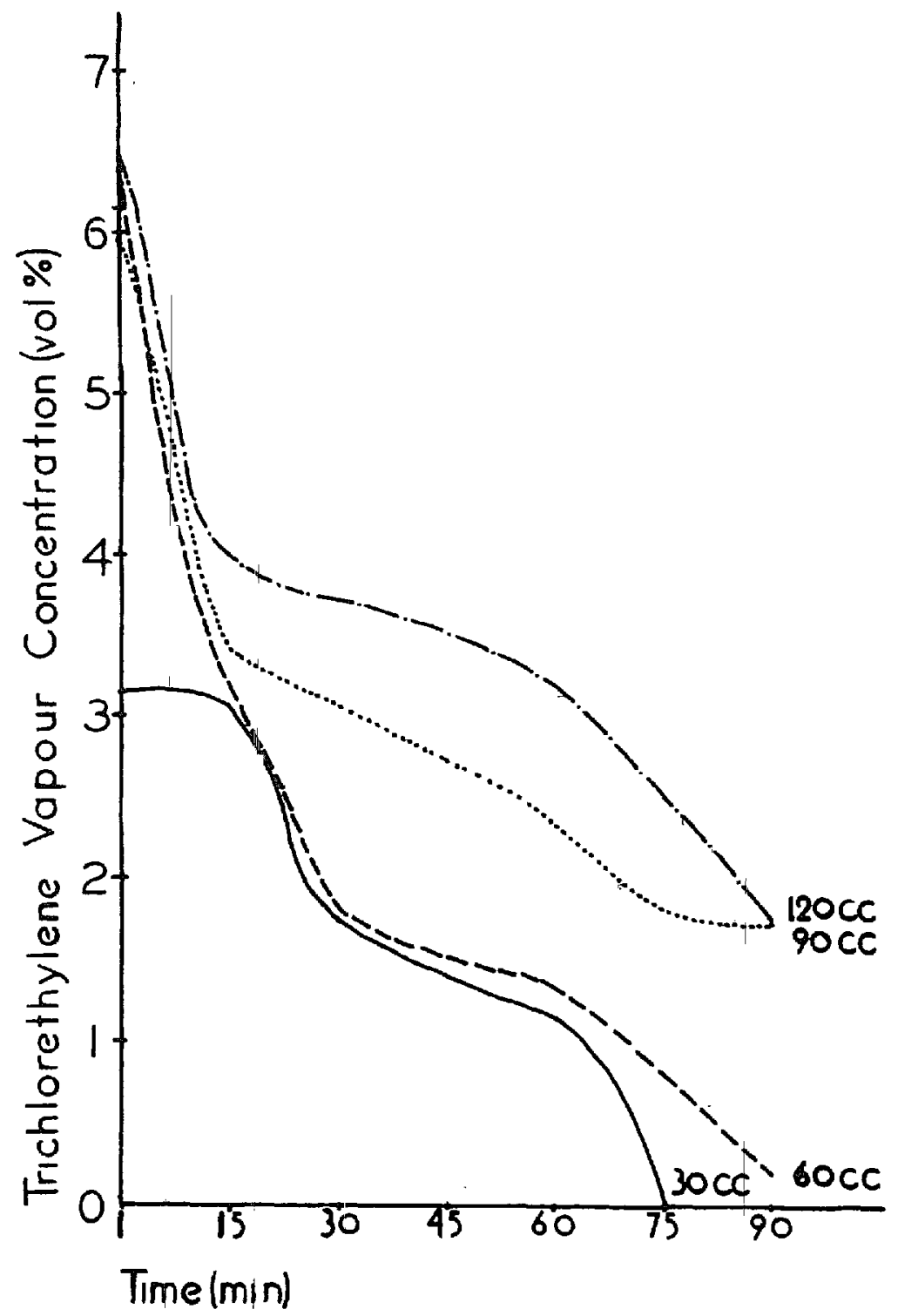

Fic. 2. Valve opening 4; flow rate $81 / \mathrm{m}$.

low concentration is observed initially; this is probably owing to the low level of liquid which prevents adequate "bubbling" for maximal vaporization to occur. The data in Table II indicate that the volume of liquid does not affect the vapour concentrations with valve openings 1,2 , and 3 , except where surface dis- 
turbance occurs. When the level of trichlorethylene was opposite any of the openings of the central metal core, the surface was agitated and the concentration increased temporarily to a variable degree.

The effect on vapour concentration due to cooling of the trichlorethylene approximately 4.2 degrees below room temperature, was obviously minimal. In experiments with a greater fall in temperature, it was impossible to separate the reduction in concentration due to cooling, frorn that due to other factors. However, the normal vapour pressure curve of trichlorethylene "flattens" at room temperature (1), so that even a large fall in temperature does not greatly reduce its concentration. The minimal effect of temperature on trichlorethylene concentraton is in marked contrast to the known effect of temperature on ether concentrations.

\section{Conclusions}

It is evident that the concentrations obtained with valve opening 4 are too high for contınuous administration during anaesthesia (2). "Bubbling" should be avoided, since these high concentrations are only obtained when it occurs.

The concentrations obtained with valve openings 1,2 , and 3 lie withm the clinical range. They are little affected by alterations in flow rate, fluid volume, and liquid temperature but do show transient minor increases with surface disturbances.

\section{SUMMARX}

The trichlorethylene vapour concentrations delivered by a standard anaesthetic machine were determined at room temperature and atmospheric pressure. The effect on these concentrations by changes in valve opening, rate of gaseous flow, fluid volume, and liquid temperature was observed and discussed.

It was shown that with valve opening 4 , a progressive fall in vapour concentration occurred from a high initial level. At this valve setting, the concentration tended to decrease as gaseous flow was increased, and to rise as the fluid level was increased. A decrease in liquid temperature appeared to have little effect on vapour concentration, which is in marked contrast to the known effect of temperature on ether concentrations.

The vapour concentrations attamed with valve opening 4 are too high for continuous clinical use. Since these high concentrations are always associated with bubbling of the gas through the trichlorethylene, it is suggested that "bubbling" be avoided during anaesthesia.

The vapour concentrations increased as the valve was opened from 1 to 3 . At each valve setting, the initial concentration remained almost constant despite changes in gaseous flow rate, flud volume, and liquid temperature. A slight increase in concentration occurred if a surface disturbance was created. The vapour concentrations attained with valve openings 1,2 , and 3 are within the clinical range.

\section{RÉSUMÉ}

Les concentrations de vapeur de trichloréthylène émises par une machine anesthésique standard ont été déterminées à la température environnante et 
sous la pression athmosphérique. On a observé et discuté les effets produits sur ces concentrations par les changements apportés à l'ouverture de la valve, au débit du flot gazeux, au volume du fluide et à la température du liquide.

On a démontré qu'avec une ouverture de valve 4 , il se produisait une chute progressive dans la concentration de la vapeur à partir d'une forte proportion initiale. Avec ladite ouverture, la concentration tendait à décroître quand on augmentait le flot gazeux et à s'élever quand on augmentait le débit du fluide. Une baisse dans la température du liquide a paru n'avoir que peu d'effet sur la concentration de la vapeur, ce qui est en net contraste avec les effets connus de la température sur les concentrations d'éther.

Les concentrations de vapeur atteintes avec une ouverture de valve 4 sont trop élevées pour un emploi clinuque continu. Ces fortes concentrations étant toujours accompagnées d’un barbotage du gaz dans le trichloréthylène, on suggère d'éviter le barbotage pendant l'anesthésie.

Les concentrations de vapeur augmentalent quand on ouvrait la valve de 1 à 3 . Pour chacue position de la valve, la concentration initiale restait presque constante ma.gré les changements apportés au débit gazeux, au volume du fluide et à la température du liquide. Il se produsait une légère élévation de concentration si lon en agitait la sufface. Les concentrations de vapeur atteintes avec des ouvertures de valve 1,2 et 3 , sont du domaine clinique normal.

\section{REFERENCES}

1. Macintosi, R. R. and Musims, W W Physics for the Anaesthetst. 1st ed., Toronto. The Ryerson Press (1947).

2. Ostuere, Gordon Trichlorethylene Anaesthesia. Ist ed., London. E. and S. Livingstone (1953). 